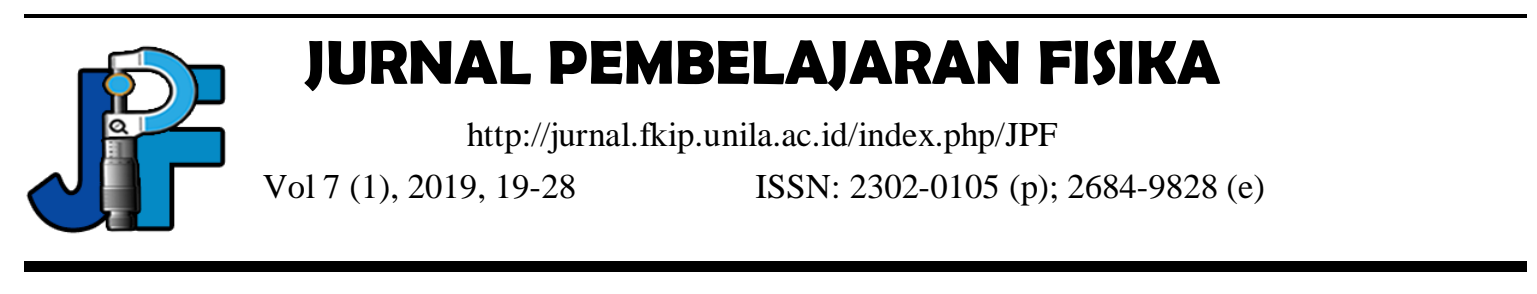

\title{
The Implementation of Performance Assessment Instruments to Enhance Students' Collaboration and Communication Skills
}

Nia Sumiyati*, Undang Rosidin, Agus Suyatna

FKIP Universitas Lampung, J1. Prof. Dr. Soemantri Brojonegoro No. 1 Bandar lampung

*e-mail: niasumiyati97@gmail.com

\begin{abstract}
This research aims to describe the relationship between student performance in physics learning based practicum on students' collaboration and communication skills of senior high school students. This study is quasi-experiment research. This study also tested the validity and reliability of the assessment instruments, and for data tested by using correlation test. The conclusion of this study is that there is no relationship between student performance on physics practicum based learning with students' collaboration and communication skills.
\end{abstract}

Keywords: collaboration skill, communication skill, performance assesment

DOI: http://dx.doi.org/10.23960/jpf.v7.n1.201904 



\section{INTRODUCTION}

Physics subjects are always closely related to everyday life or the real world, to prove the theory that students learn with the real world requires practical activities. According to Usman (2014) that the application of the 2013 curriculum emphasizes the scientific approach, giving responsibility to teachers to design activities so students can carry out scientific activities or practicum. With practicum activities, students will more easily absorb the core lessons learned so that the practical process is very important to be applied in learning physics in improving the ability or understanding of students. Practical activities later certainly need a performance assessment carried out by the teacher. This performance assessment is conducted to measure how far students have mastered the material learned and used to evaluate student learning outcomes. Performance assessment is needed by the teacher to obtain information in an objective, sustainable and comprehensive manner about the process and student learning outcomes, the results of which are used as a basis for determining subsequent treatment.

Learning efforts should be so that students have a harmonious life that is living together with others, working together in groups, respecting each other's opinions, respecting people speaking, responsibility, willing to sacrifice, accommodating and having a big spirit in improving students' abilities. Students' abilities referred to here are collaboration and communication skills. Collaborative is a philosophy of interaction and lifestyle that is used as cooperation as an interaction structure designed in such a way as to facilitate collective effort to achieve common goals. The thoughts that underlie collaborative abilities are fostered through cooperation between group members as opposed to competitions that prioritize individual excellence. Communicative ability is an activity or process that must be carried out by students conducted interactively, inspirational, fun, challenging, motivating students to actively participate.

Based on the Republic of Indonesia Minister of Education and Culture Regulation No. 23 of 2016 concerning Standard Education Assessment, assessment of the performance of learning outcomes by teachers aims to monitor and evaluate the process, learning progress, and continuous improvement of student learning outcomes. Performance assessment applied to students in the form of tests, observations, assignments, and/or other forms needed. Assessment of the performance of student learning outcomes in primary and secondary education includes aspects: attitudes, knowledge, and skills.

Teacher practicum activities can apply authentic assessment that covers the domain of attitudes, knowledge, and skills. Practical activities in physics learning enable the application of authentic types of assessment of performance (performance assessment) to students' collaboration and communication skills. Performance is done by observing student activities in doing something that applies knowledge and skills. Performance is obtained from the results of the teacher's observation of student activities as they occur. Performance is usually used to assess students' ability to identify problem solving, think logically, use practical tools and other activities that can be observed so that student learning outcomes will be seen based on the learning process and in accordance with the abilities of each student's skills.

Previous study has not disscused about the relationship between student performance in physics learning based practicum on students' collaboration and communication skills of senior high school students. Therefore, this study is focused on it. 


\section{METHOD}

This research was conducted at MAN 2 Bandar Lampung even semester of the 2018/2019 academic year. The population of this study was MAN 2 Bandar Lampung in the 2018/2019 academic year. Study sample of class XI IPA 1. The research design used in this study was quasi-experiment using descriptive methods. The instruments used at the time of the research were performance assessment instruments, cognitive abilities and communicative abilities of the instruments used by expert testing (Sukmawa, 2015)

Test the validity of the three instruments used during the practicum, namely using collaboration skill, communication skill, and student performance instruments that have been previously developed by Oki Sukmawa. Validity test is used to determine the feasibility of items in a list of questions in defining a variable. This list of questions generally supports a certain group of variables. Validity test is carried out on each item that is tested for validity. Our results compare with where with. If it is valid, furthermore, reliability testing can be carried out together on all items. If the Alpha value is $>0.60$ then it is reliable and the last is the correlation test by squaring the correlation coefficient ( $r$ count) found, to see the effect in the form of a percentage.

\section{RESULT AND DISCUSSION \\ Validity Test Results and Instrument Reliability Validity}

The results of the three instruments used during practicum were, using collaboration skill, communication skill, and student performance instruments that had been developed previously by Oki Sukmawa. Validity test is used to determine the feasibility of items in a list of questions in defining a variable. This list of questions generally supports a certain group of variables. Validity test is carried out on each item that is tested for validity. Our results compare with where with. If it is valid, the first stage of analysis using the number of respondents 40 students, the $r$ table is obtained through table $r$ Pearson product moment with df (degree of freedom), so, then. Item statement is said to be valid if it is a value. The instrument consisting of 40 students then $\mathrm{r}$ table is obtained through table $\mathrm{r}$ Pearson product moment with df (degree of freedom). Then it can be concluded that all instruments used are all valid. Furthermore, if the score obtained after being calculated as a whole from the collaboration skill instrument if the average score is converted into a qualitative value it will be "good"

Table 1. Test the Validity of Communication Skill of students

\begin{tabular}{llll}
\hline Variable & $r_{\text {calculate }}$ & $r_{\text {table }}$ & Category \\
\hline Indicator 1 & 0.534 & 0.3061 & Valid \\
Indicator 2 & 0.558 & 0.3061 & Valid \\
Indicator 3 & 0.370 & 0.3061 & Valid \\
Indicator 4 & 0.354 & 0.3061 & Valid \\
\hline
\end{tabular}

Table 1 can be concluded that the communication skill instrument consisting of 40 students then the $r$ table is obtained through table $r$ Pearson product moment with $\mathrm{df}$ (degree of freedom). Can be concluded that all instruments used are all valid. Furthermore, if the score obtained after being calculated as a whole from the collaborative ability instrument if the average score is converted into a qualitative value it will be "good". The performance instrument used at the time of the study consisting of 40 students, then the $r$ table is obtained through table $r$ Pearson product moment with $\mathrm{df}$ 
(degree of freedom), then it can be concluded that all instruments all used are valid. Furthermore, the final value on the performance instrument after being calculated as a whole, the average score $>75$ will get quality or quality letters "Very Good"

\section{Reliability}

Reliability test is an index that shows the extent to which measurement tools can be trusted. Instrument reliability is needed to obtain data in accordance with the measurement objectives. Reliability is a measure of the stability and consistency of respondents in answering things related to contract construction questions which are dimensions of a variable and arranged in the form of an instrument. Reliability testing can be carried out jointly on all items. If the Alpha value> 0.60 then it is reliable. Reliable test value can be seen from the value of Cronbach's Alpha.

Table 2. Interpretation of Reliability

\begin{tabular}{cc}
\hline Correlation coefficient & Reliability Criteria \\
\hline $0,80<\mathrm{r}<1,00$ & Very High \\
$0,60<\mathrm{r}<0,80$ & High \\
$0,40<\mathrm{r}<0,60$ & Enough \\
$0,20<\mathrm{r}<0,40$ & Low \\
$0,00<\mathrm{r}<0,20$ & Very Low \\
\hline & (Sugiyono, 2014)
\end{tabular}

The following are the results of the test using SPSS 21 from the three instruments that were used at the time of the study. The Cronbach Alpha value of collaborative ability instrumen of 0.783 , which means that according to the interpretation of the reliability of the correlation coefficient $0.60<\mathrm{r}<0.80$, the reliability criteria are classified as high categories. Then, a value of Cronbach's Alpha of performance instruments is 0.726 which means that according to the interpretation of the reliability of the correlation coefficient $0.60<\mathrm{r}<0.80$, the reliability criteria are classified as high categories.

\section{Correlation Test Results}

Correlation test is used to find the degree of closeness of the relationship between student performance on physics practicum-based learning with students' collaboration skill and the relationship of student performance to practicum-based learning with students' communication skill, the higher the correlation value the higher the closeness of the relationship between the two variables. Through correlation analysts we can find out the coefficient of determination which aims to see how much the influence of the variables one and the other variables, namely by squaring the correlation coefficient ( $r$ count) found, to see the effect in the form of percentages. If $r$ count is smaller than $\mathrm{r}$ table ( $\mathrm{r}$ count $<\mathrm{r}$ table) then $\mathrm{H}_{0}$ accepted, and $\mathrm{H}_{1}$ rejected. But conversely if $r$ count is greater than $r$ table ( $r$ count $>r$ table) then $\mathrm{H}_{0}$ is rejected, and $\mathrm{H}_{1}$ is accepted. The following are the results of statistical tests using SPSS to find out the relationship between student performance in physics practicum based learning with students 'collaborative abilities and the relationship between student performance on physics practicum-based learning and students' communicative abilities.

Table 3. Relationship between student performance in physics practicum-based learning with students' collaboration skill. 
Table 3 is a correlation test. It can be concluded that there is no relationship

\section{Correlations}

\begin{tabular}{cccc} 
& & Performance & Collaboration \\
\hline \multirow{4}{*}{ Performance } & Pearson & 1 & .058 \\
& Correlation & & .722 \\
& Sig. (2-tailed) & & 40 \\
\hline \multirow{3}{*}{ N } & Pearson & .058 & 1
\end{tabular}

Collaborative Sig. (2-tailed)

$\mathrm{N}$ 40

41

between student performance on physics practicum-based learning and students' collaboration skill because the sig value $\geq 0.05$ and $r=0.058$ which means based on the correlation interval above that of the coefficient interval $0.60-0.79$ does not correlate or has no relationship.

Table 4. Relationship between student performance in physics practicum-based learning and students' communication skill.

\begin{tabular}{cccc}
\hline & \multicolumn{2}{c}{ Correlations } \\
Performance & Communication \\
\hline \multirow{4}{*}{ Performance } & Pearson & 1 & -.176 \\
& Correlation & & .278 \\
& Sig. (2-tailed) & & 40 \\
\hline \multirow{5}{*}{ Communication } & $\mathrm{N}$ & 40 & 1 \\
& Pearson & -.176 & \\
& Correlation & & 40 \\
& Sig. (2-tailed) & .278 & 40 \\
\hline
\end{tabular}

Table 4 is between performance and communication skill. It can be concluded that there is no relationship between student performance on physics practicum based learning with students' communication skill because the sig value $=\geq 0.05$ and $r=$ 0.176 which means based on the above correlation interval from the interval coefficients of 0.20-0.39 categorized as having no relationship or uncorrelated.

Based on the correlation test that has been obtained, there is no relationship between student performance in physics practicum-based learning with students' collaboration skill, because the sig value $\geq 0.05$ and $r=0.58$ which means based on the correlation interval above that of the coefficient interval of 0.60- 0.79 categorized as uncorrelated. The value of the coefficient cannot describe the causal relationship between the variable performance and collaboration skill. To arrive at a cause and effect relationship, more intensive research is needed or can be based on existing theories where performance influences collaboration or collaboration skill that affect performance. In addition, in analyzing the relationship between performance and collaboration skill, of course, there must be a logical relationship between the two variables. Researchers cannot arbitrarily measure the correlation coefficient between performance and collaboration skill because logically the level of performance has no relationship with the level of collaboration skill. 
There are several reasons why there is no relationship between performance and collaboration skill. There are several reasons that can be seen, which can be seen in each performance indicator with collaboration skill, that in each indicator of student performance assessment describes all the classification processes of practical activities. and communicating while each indicator of collaboration skill only illustrates sharing experiences, responsibilities, sharing information, cooperating, supporting innovation, mutual trust and respect. This means that each performance indicator with collaboration skill is not mutually influential or unrelated. Performance indicators can only be used when students carry out practical activities and collaboration indicators of ability of students to work together effectively with various parties to solve problems and improve intellectual development. Also explained by Karviyani (2015), performance appraisal is suitable to be used to assess the achievement of competencies that require students to perform certain tasks such as practical activities. With practical activities students will be given the opportunity to follow the process, observe an object, analyze, prove, and draw their own conclusions about an object, situation or something. Based on the results of the research Khun (2015) stated that cooperation is seen as a process that leads to other desired individual and group results, such as success in solving problems and increasing intellectual development.

Based on the correlation test results there is no relationship between student performance on physics practicum-based learning with students' communication skill because it gets the sig value $\geq 0.05$ and $r=-0.176$ which means based on the correlation interval above that of the coefficient interval 0.20-0,39 categorized as a low level of connection. This means that there is no relationship between student performance on physics practicum-based learning with students' communication skill.

The reason that there is no relationship between performance and communication skill is that researchers must consider other factors in terms of respondents. There are respondents who estimate honest answers, there are respondents who are dishonest, so negative correlations are not caused by data errors but various factors. Negative correlation does not mean that the results of the study or data are wrong. The reason that there is no relationship between student performance and communication skill is that each performance indicator with collaboration skill can be seen, that in each indicator of student performance assessment describes all classification processes of practical activities starting from observing, asking, trying, associating. Whereas if the researcher looks at each indicator of communication skill.

According to Trilling et al. (2009) indicators of communication skill that include students can articulate ideas, be able to listen to the abilities of others, utilize existing media, are able to communicate effectively correctly in various environmental differences. This means that each performance indicator with communication skill is not mutually influential or unrelated. In the results of the research (Soeharto, 1995) communication skill is a process of providing information, messages, ideas, ideas, thoughts, these feelings become shared property between cominators and communicants.

\section{CONCLUSION}

The results of research and discussion it can be concluded that there is no relationship between student performance in physics practicum-based learning with collaborative abilities of students with sig value $\geq 0.05$ and $r=0.058$ means that there is no relationship and there is no relationship between student performance in practicum 
based learning physics with students' communicative abilities is obtained sig $=0.05$ and values $r=-0,176$.

\section{REFERENCES}

Karviyani, Sevi. (2015). Pengembangan Instrumen Asesmen Kinerja Praktikum pada Materi Titrasi Asam Basa.Jurnal Pendidikan dan Pembelajaran Kimia. Vol 4. No 1. Hal 3.

Kuhn, Deanna. (2015). Thinking Together and Alone. Educational Researcher, 44(1): 46-53. (Online). Diakses melalui http://www.researchgate.net/publication/ 274566803 pada tanggal 15 September 2018 pukul 18.32 WIB.

Soeharto, Karti. 1995. Teknologi Pendidikan. Bandung: Bina Aksara.

Sugiyono. (2014). Metode Penelitian Pendidikan. Bandung: Alfabeta.

Sukmawa, O., Rosidin, U., \& Sesunan, F. (2019). Pengembangan Instrumen Asesmen Kinerja (Performance Assessment) Praktikum Pada Mata Pelajaran Fisika di SMA. Jurnal Pendidikan Fisika. Vol. VII. No.1.

Trilling, Barnie, Fadell,Wiley. (2009). 21th Century Skill: Learning For Life In Our Times. Jossey-Bass A Wiley Imprint, San Fransisco. USA

Usman. (2014). Pengembangan Perangkat Penilaian Kinerja Praktikum Fisika pada Peserta Didik SMP Unismuh Makassar. Jurnal Sains dan Pendidikan Fisika. Jilid 10. No 3. Hal 3. 